\title{
РЕДКОЗЕМЕЛЬНЫЕ И РАДИОАКТИВНЫЕ (ТН, Ч) ЭЛЕМЕНТЫ В КОМПОНЕНТАХ ПРИРОДНОЙ СРЕДЫ НА ТЕРРИТОРИИ ТОМСКОЙ ОБЛАСТИ
}

\author{
Барановская Наталья Владимировна ${ }^{1}$, \\ nata@tpu.ru
}

\author{
Агеева Елена Владимировна', \\ ev_ageeva@mail.ru \\ Соктоев Булат Ринчинович1, \\ bulatsoktoev@tpu.ru \\ Наркович Дина Владимировна', \\ shvezova_d@mail.ru
}

\section{Денисова Ольга Александровна², oadeni@yandex.ru}

\author{
Матковская Тамара Васильевна², \\ matkovskay@inbox.ru \\ 1 Национальный исследовательский Томский политехнический университет, \\ Россия, 634050, г. Томск, пр. Ленина, 30. \\ 2 Сибирский государственный медицинский университет Министерства здравоохранения Российской Федерации, \\ Россия, 634050, г. Томск, Московский тракт 2.
}

\begin{abstract}
Актуальность исследования обусловлена необходимостью рассмотрения взаимосвязей радиоактивных и редкоземельных элементов с точки зрения их высокой индикаторной роли в комплексе компонентов природной среды на локальных территориях, характеризующихся различными природно-техногенными условиями и условиями районирования территории с учетом биогеохимических показателей.

Цель: рассмотрение взаимосвязей радиоактивных и редкоземельных элементов в комплексе компонентов природной среды на территории Томской области, характеризующейся различными природно-техногенными обстановками.

Методы: основной метод исследования - инструментальный нейтронно-активационный анализ, который осуществлялся на базе исследовательского ядерного реактора Национального исследовательского Томского политехнического университета. Определено содержание двух радиоактивных - тория и урана, а также семи редкоземельных (La, Ce, Sm, Eu, Tb, Yb, Lu) элементов.

Результаты. Оиенено содержание редкоземельных и радиоактивных элементов в четырех параллельно отобранных и изученных компонентах природной среды на территории Томской области: почва, солевые отложения природных пресных вод (накипь), волосы и кровь человека. Содержание изученных элементов максимально для почв и накипи и значительно ниже в биосубстратах человека. Волосы и кровь человека как живые ткани характеризуются резким иериевым минимумом. В крови выявлен иттербиевый максимум, вероятно, связанный с нахождением этого элемента в виде металлорганических комплексов. Исследованы соотношения химических элементов, которые можно использовать в качестве индикаторов природнотехногенных обстановок. Проведено районирование Томской области по междуречьям бассейна реки Обь по частоте встречаемости аномальных содержаний редкоземельных и радиоактивных элементов во всех изученных компонентах.
\end{abstract}

\section{Ключевые слова:}

Редкоземельные и радиоактивные элементы, компоненты природной среды, индикаторные показатели, соотношения элементов, Томская область, биогеохимическое районирование территории.

\section{Введение}

К редкоземельным элементам (РЗЭ, в англоязычной литературе REE), или лантаноидам, относятся 15 элементов периодической системы химических элементов Д.И. Менделеева, которые по ряду свойств (строение атомов, физико-химические, геохимические и другие) делятся на три группы (легкие (light LREE), средние (medium - MREE), тяжелые (heavy HREE)) [1].

Несмотря на термин «редкоземельные», их среднее содержание в верхней части литосферы составляет $0,015 \%$. Например, Се по распространенности превосходит $\mathrm{Cu}$ и $\mathrm{Pb}$. Все остальные РЗЭ, кроме Pm, более распространены, чем $\mathrm{Ag}$ или $\mathrm{Hg}$ [2], а самые редкие элементы из этой группы ( $\mathrm{Lu}$ и $\mathrm{Tm})-\mathrm{Cd}$ и $\mathrm{Se}$ [3]. Наименее распространенным является Lu, содержание которого в земной коре составляет 0,5 г/т, что значимо выше содержания $\mathrm{Au}(0,0031$ г/т) [4]. В целом распределение данной группы элементов в природе подчиняется правилу Оддо-Гаркинса $[5,6]$.

Повышенный интерес к изучению РЗЭ в окружающей среде связан с вступлением современного мира в «век нанотехнологии» [7], особенностью которого является широкое использование данной группы химических элементов в передовых промышленных областях (электроника, оптика, автомобилестроение и 
другие), сельском хозяйстве (удобрения и пестициды) и медицине (магнитно-резонансная томография) $[8,9]$. Производство РЗЭ увеличилось с 30 тысяч т (1980 г.) до 150 тысяч т (2010г.) [9]. На сегодняшний день крупнейшим производителем и экспортером РЗЭ в мире является Китай, занимая практически $100 \%$ рынка [10]. Крупнейшим по запасам и добыче в Китае является REE-Nb-Fe месторождение Баян Обо (автономный район Внутренней Монголии). Запасы РЗЭ в Китае составляют около 55 млн т против 110 млн т во всем остальном мире [11]. Вопросы содержания РЗЭ в окружающей среде рассматриваются учеными многих стран мира [3, 12-18]. Крупномасштабная эксплуатация и активное использование РЗЭ неизбежно приводят к увеличению их концентрации в окружающей среде и, как следствие, в живых организмах, в том числе в организме человека.

Первые сведения о содержании отдельных Р3Э в живых организмах относятся к работам начала прошлого столетия. Исследования, касающиеся закономерностей поведения и оценки содержаний всей группы лантаноидов, не так многочисленны. Из работ российских ученых стоит отметить обзор медикобиологических свойств и распространённости РЗЭ в горных породах и водах минерализованных источников [19], а также научные исследования по изучению фосфатных и карбонатных биоминеральных образований [20]. Наиболее изучены закономерности поведения РЗЭ в геологических объектах [21-23].

РЗЭ имеет значительное сродство к естественным радиоактивным элементам: Тh и U - наиболее распространённым членам семейства актинидов. U встречается в двух степенях окисления: +4 и +6 , в то время как $\mathrm{Th}-+4$. При этом только $\mathrm{U}^{+4}$ и $\mathrm{Th}^{+4}$ наиболее близки по геохимическим свойствам к РЗЭ: размерам их ионных радиусов и кислотно-щелочным свойствам. За счет этого возможен изоморфизм данных элементов между собой: $\mathrm{U}^{4+}$ тяготеет к тяжелым Р3Э, $\mathrm{Th}^{4+}$ - к легким РЗЭ [24-27].

По данным разных авторов кларк $U$ в земной коре составляет $2,3-3 * 10^{-4} \%$, а Th $-1,3 * 10^{-3}-8,1 * 10^{-4} \%$. В почвах их содержания оцениваются в $5^{*} 10^{-4} \%$ и $6^{*} 10^{-4} \%$, соответственно [28, 29$]$.

Для живых организмов характерны очень низкие показатели накопления $\mathrm{U}$ и Th: их содержания не превышают $10^{-5} \%$. Первые количественные характеристики Th и U в живых организмах представлены в работах А.П. Виноградова [30], Дж. Хоффмана [31-33] и других. Содержание U в ежегодном приросте растительности по данным В.В. Добровольского [34] составляет $4 * 10^{-5} \%$ золы, что существенно ниже его кларка в земной коре. Исследования последних лет показывают, что резко увеличивается его накопление в биологических объектах в зонах влияния техногенеза [35]. Данных по содержанию Тh в объектах живой природы гораздо меньше, чем для U. Согласно данным отдельных авторов, среднее содержание Th в золе наземных растений $\mathrm{n}^{*} 10^{-5} \%$, а наиболее высокое содержание составляет $0,1 \%$ [36]. В целом можно отметить высокую вариативность содержания естественных радиоактивных элементов в живом веществе при их определении на отдельных территориях [27, 37].

Таким образом, актуальность изучения РЗЭ и радиоактивных элементов на локальных территориях обусловлена как глобальными изменениями в их миграции, так и высокой индикаторной ролью их содержания и соотношения на участках с природными и техногенными геохимическими аномалиями [27, 37-40]. При этом следует учитывать возможность возникновения токсического эффекта от их воздействия на живые организмы [41-45].

Территория Томской области характеризуется наличием потенциальных источников поступления РЗЭ и радиоактивных элементов в компоненты природной среды. Таковыми являются угольные залежи Центральной Сибири, характеризующиеся повышенными содержаниями данных элементов относительно угольного кларка. Данные элементы могут поступать в окружающую среду при сжигании углей [46]. Дополнительным источником являются месторождения циркон-ильменитовых песков, широко распространенных на территории области [47]. При разработке этих месторождений РЗЭ и радиоактивные элементы могут быть вовлечены в трофические цепи. В Томском районе располагается Северный промышленный узел, где на ограниченной территории сконцентрировано значительное количество промышленных объектов. Наиболее крупные промышленные объекты ядерно-топливного цикла - Сибирский химический комбинат (СХК), нефтехимической отрасли - ООО «Томскнефтехим», агропромышленных комплексов птицефабрика «Межениновская», свинокомплекс «Томский» и другие.

Целью данной работы является рассмотрение взаимосвязей радиоактивных и РЗЭ в комплексе компонентов природной среды (почва, солевые отложения природной пресной воды) и организма человека (волосы и кровь) на территории Томской области, характеризующейся различными природно-техногенными условиями.

\section{Объекты и методы исследований}

Работа базируется на 1235 пробах компонентов природной среды, отобранных в период с 2000 по 2011 гг. на территории Томской области. Параллельно отобраны почвы частных приусадебных хозяйств (184 пробы), солевые отложения природных пресных вод (накипь) (278 проб), волосы человека (562 пробы) и кровь человека (211 проб). При проведении исследования рассматривались населенные пункты Томской области, располагающиеся в рамках междуречий Оби и ее крупных притоков (рис. 1). Обь-Чулымское междуречье включает 170 населенных пунктов шести административных районов (Асиновский, Томский, Зырянский, Тегульдетский, Кривошеинский, Шегарский). Кеть-Чулымское междуречье охватывает 51 населенный пункт пяти административных районов (Верхнекетский, Колпашевский, Томский, Молчановский, Первомайский). Обь-Васюганское междуречье включает 134 населенных пункта девяти адми- 
нистративных районов (Бакчарский, Каргасокский, Кожевниковский, Колпашевский, Кривошеинский, Молчановский, Парабельский, Чаинский, Шегарский).
Отбор и подготовка проб проводились в соответствии с инструкциями и требованиями к геохимическим и геолого-экологическим исследованиям.

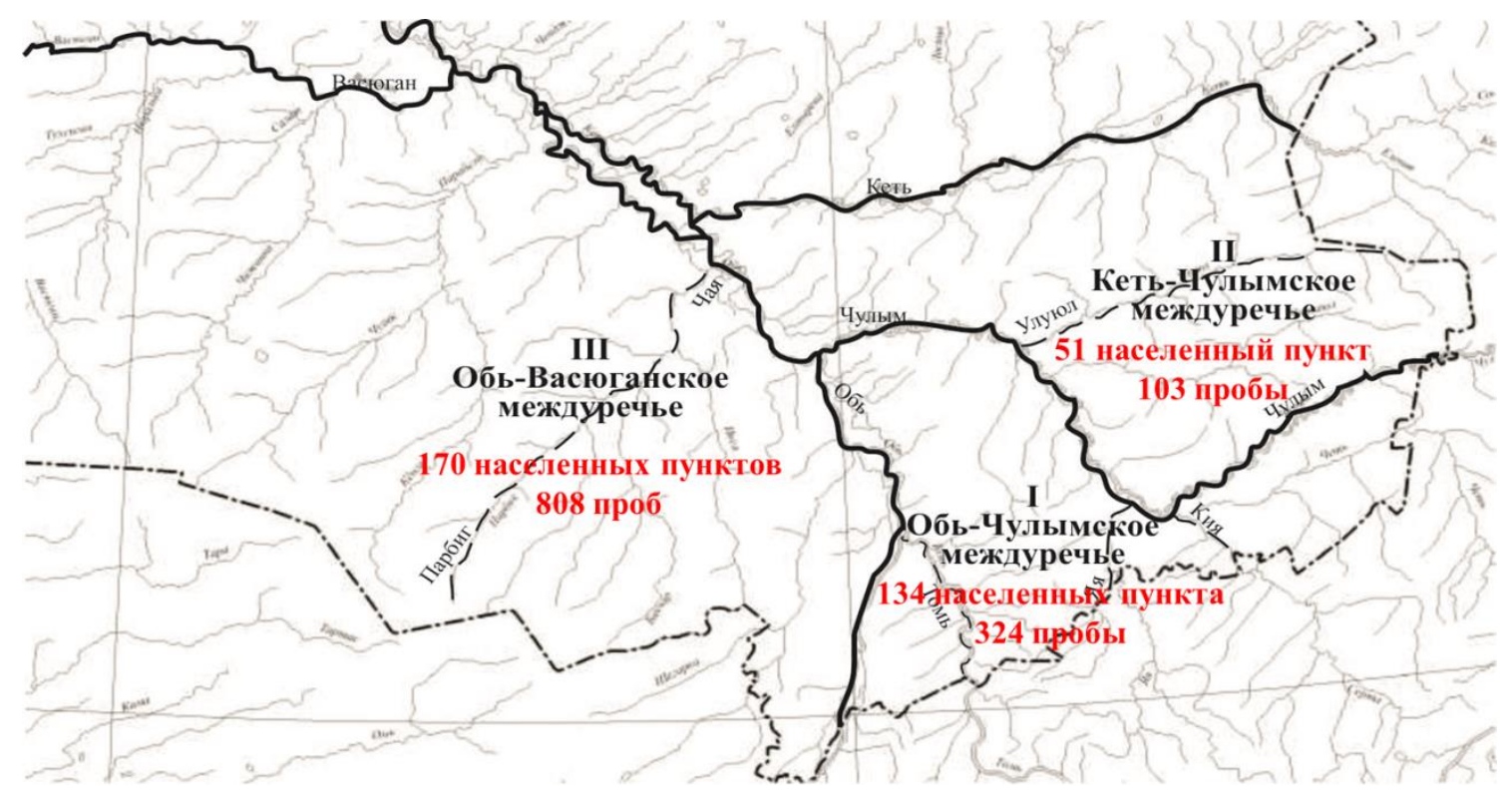

Pис. 1. Карта-схема отбора проб на территории междуречий Оби и ее крупных притоков

Fig. 1. Map of sampling on the territory of Ob interfluves and its major tributaries

При отборе почв руководствовались ГОСТ 17.4.3.01-83, ГОСТ 17.4.4.02-84 и методическими наработками коллектива ИМГРЭ (1997) [48-50]. Почвы на приусадебных хозяйствах отбирались методом конверта со стороной $10 * 10$ м, на глубине $15 \mathrm{~cm}$, масса пробы составляла 200-250 г. Проба высушивалась, просеивалась на сите диаметром отверстий в 2 мм, истиралась до состояния «пудры».

Для солевых отложений природных пресных вод (накипи) использовали патент «Способ определения участков загрязнения ураном окружающей среды» [51]. Накипь отбиралась из посуды, в которой кипятилась вода. При отборе фиксировали глубину залегания водоносного горизонта и тип посуды. Объем пробы составлял 20-50 г. Пробоподготовка включала высушивание образцов при комнатной температуре и истирание в агатовой ступке до состояния «пудры».

При отборе волос и крови человека действовали согласно рекомендациям МАГАТЭ (1980) [52]. При взятии проб волос фиксировали пол, полное имя, возраст, место рождения и адрес проживания, а также наличие патологий и хронических заболеваний. В выборку были включены дети в возрасте 2-16 лет, которые были рождены в данном населенном пункте и не имели изменений по медицинским показателям. Пробоподготовка заключалась в измельчении волос до сегментов длиной 0,5 см. Кровь для исследования предоставлена сотрудниками СибГМУ. Предоставленные образцы высушивались в муфельной печи при температуре $60{ }^{\circ} \mathrm{C}$ до твердого состояния.

Основной метод исследования - инструментальный нейтронно-активационный анализ, который осуществлялся на базе исследовательского ядерного реактора Национального исследовательского Томского политехнического университета (аналитики А.Ф. Судыко, Л.В. Богутская). Было определено содержание двух радиоактивных элементов (Th, U) и семи РЗЭ (La, Ce, Sm, Eu, Tb, Yb, Lu).

Для интерпретации и анализа данных проводился стандартный анализ среднестатистических параметров с использованием программ STATISTICA 8 и Excel. Для оценки различий средних значений использовался критерий Манна-Уитни $(\mathrm{p}=0,05)$. Для выявления статистически значимых аномалий редкоземельных и радиоактивных (Th, U) элементов в компонентах природной среды были выделены значения отличные от $\mathrm{x} \pm 3 \mathrm{~S}$, где $\mathrm{x}$ - среднее арифметическое содержание элемента; S - среднее квадратичное отклонение [53].

Для выявления индикаторных показателей использовались соотношения элементов: $\mathrm{Th} / \mathrm{U}, \mathrm{La} / \mathrm{Ce}, \mathrm{La} / \mathrm{Yb}$, $\mathrm{La}+\mathrm{Ce} / \mathrm{Sm}+\mathrm{Eu}, \mathrm{La}+\mathrm{Ce} / \mathrm{Yb}+\mathrm{Lu}$, а также сумма редкоземельных элементов: $\sum$ P3Э=La+Ce+Sm+Eu+Tb+Yb+Lu.

\section{Результаты и их обсуждение}

Анализ средних содержаний изученных элементов (таблица) показывает, что концентрация РЗЭ и радиоактивных элементов существенно выше в компонентах природной среды (почва и накипь), и значительно ниже в организме человека (волосы и кровь). Распределение РЗЭ подчиняется правилу Оддо-Гаркинса. По мере снижения концентрации элементов изученные объекты можно выстроить в следующий ряд «почва-накипь-волосы-кровь» и только в случае с U данный ряд нарушается. Хорошо известно, что $U$ в водных растворах мигрирует в валентности +6 в форме $\left(\mathrm{UO}_{2}\right)^{2+}$ совместно с $\left(\mathrm{CO}_{3}\right)^{2-}[24,54]$. Вероятно, этим обусловлено низкое $(0,05)$ значение $\mathrm{Th} / \mathrm{U}$ отно- 
шения в накипи. Эта особенность, характерная для почв и вод в целом, описана Л.П. Рихвановым [55].

Соотношения РЗЭ или их групп часто применяются для их дифференциации и выявления особенностей компонентов природной среды. Такие показатели также являются индикатором смены геохимических условий [21, 38]. Нами были использованы такие отношения, как $\mathrm{La} / \mathrm{Ce}, \mathrm{La} / \mathrm{Yb}, \mathrm{La}+\mathrm{Ce} / \mathrm{Sm}+\mathrm{Eu}$, $\mathrm{La}+\mathrm{Ce} / \mathrm{Yb}+\mathrm{Lu}$.

$\mathrm{La} / \mathrm{Ce}$ отношение является наиболее индикаторным, так как его значения изменяются в узком диапазоне от 0,3 для накипи до 0,8 для волос. Кровь человека характеризуется наименьшими значениями $\mathrm{La} / \mathrm{Yb}$ и $\mathrm{La}+\mathrm{Ce} / \mathrm{Yb}+\mathrm{Lu}$ отношений. А.В. Дубинин [38] связывает накопление тяжелых РЗЭ на взвешенном органическом веществе с устойчивостью поверхностных комплексных соединений. Вероятно, органическое вещество влияет на изменение концентрации $\mathrm{Yb}$ и $\mathrm{Lu}$ в крови человека.

В практике геохимических исследований широко распространено нормирование содержаний РЗЭ к их содержанию в эталонных образцах с целью определения процессов фракционирования элементов в различных физико-химических условиях [56]. Наиболее распространенными эталонными образцами, используемыми для нормирования, являются: хондриты (хондритовый метеорит $\mathrm{C} 1$ ), североамериканский сланец (NASC), пост-архейский австралийский сланец (PAAS) и другие. Нормирование на «сланцы» обычно используется в исследованиях окружающей среды [12]. В нашем исследовании мы пронормировали содержания изученных РЗЭ к североамериканскому сланцу (NASC).

В результате нормирования (рис. 2) каждый из изученных компонентов показал собственную специфику, что позволило наблюдать различия между компонентами. Для почв характерно относительно однородное накопление с очень слабыми отрицательными аномалиями $\mathrm{Ce}$ и Еu. В солевых отложениях природных пресных вод отмечаются положительные аномалии $\mathrm{Sm}$ и $\mathrm{Tb}$ и отрицательные аномалии $\mathrm{Eu}$ и $\mathrm{Yb}$. В волосах наблюдаются резкие $\mathrm{Ce}$ и $\mathrm{Yb}$ минимумы. В крови при нормировании на NASC наблюдается резкий Се минимум и $\mathrm{Yb}$ максимум и в целом увеличение тяжелых РЗЭ. Схожее поведение тяжелых РЗЭ отмечается для морской воды и некоторых геологических формаций с высоким содержанием органического вещества $[38,57]$, что объясняется изменением констант устойчивости комплексных соединений. Поскольку ряд авторов [58] отмечает схожесть крови человека с морской водой, мы считаем возможным, что данный $\mathrm{Yb}$ максимум объясняется нахождением $\mathrm{Yb}$ в виде металлорганических комплексов. Устойчивость к комплексобразованию и количество органического вещества может обуславливать наличие отрицательной аномалии Се в волосах и крови человека.

Таблица. Содержание РЗЭ и радиоактивных элементов в компонентах природной среды и биосубстратах человека, мг/кг

Table. Content of rare earth and radioactive elements in the components of the environment and human biosubstrates, $m g / k g$

\begin{tabular}{|c|c|c|c|c|}
\hline \multirow[b]{2}{*}{$\begin{array}{l}\text { Элемент } \\
\text { Elements }\end{array}$} & \multicolumn{4}{|c|}{ Объект исследования/ Object of investigation } \\
\hline & $\begin{array}{c}\text { Почва } \\
\text { Soil (184) }\end{array}$ & $\begin{array}{c}\text { Солевые отложения природных } \\
\text { пресных вод } \\
\text { Salt sediment of water (278) }\end{array}$ & $\begin{array}{l}\text { Волосы человека } \\
\text { Human hair (562) }\end{array}$ & $\begin{array}{l}\text { Кровь человека } \\
\text { Human blood (211) }\end{array}$ \\
\hline \multirow{2}{*}{$\mathrm{La}$} & $23 \pm 0,5$ & $0,5 \pm 0,04$ & $0,3 \pm 0,01$ & $0,1 \pm 0,01$ \\
\hline & $\overline{7,7-43,4}$ & $\overline{0,007-5,8}$ & $\overline{0,0004-2,8}$ & $\overline{0,003-2,4}$ \\
\hline \multirow{2}{*}{$\mathrm{Ce}$} & $45 \pm 1$ & $2 \pm 0,2$ & $0,4 \pm 0,02$ & $0,2 \pm 0,01$ \\
\hline & $\overline{12,8-92,5}$ & $\overline{0,04-22}$ & $\overline{0,002-5,1}$ & $\overline{0,003-1,2}$ \\
\hline \multirow{2}{*}{ Sm } & $4,5 \pm 0,1$ & $0,2 \pm 0,04$ & $0,1 \pm 0,001$ & $0,03 \pm 0,003$ \\
\hline & $\overline{1,2-8,9}$ & $\overline{0,005-8,7}$ & $\overline{0,001-1,4}$ & $\overline{0,001-0,5}$ \\
\hline \multirow{2}{*}{$\mathrm{Eu}$} & $0,8 \pm 0,03$ & $0,06 \pm 0,01$ & $0,01 \pm 0,001$ & $0,01 \pm 0,0002$ \\
\hline & $\overline{0,05-1,7}$ & $\overline{0,005-0,9}$ & $0,001-0,2$ & $0,002-0,01$ \\
\hline \multirow{2}{*}{$\mathrm{Tb}$} & $0,7 \pm 0,02$ & $0,04 \pm 0,003$ & $0,01 \pm 0,0004$ & $0,01 \pm 0,0005$ \\
\hline & $\overline{0,2-2,4}$ & $0,01-0,5$ & $\overline{0,004-0,06}$ & $0,01-0,03$ \\
\hline \multirow{2}{*}{$\mathrm{Yb}$} & $2,4 \pm 0,07$ & $0,08 \pm 0,01$ & $0,03 \pm 0,002$ & $0,06 \pm 0,002$ \\
\hline & $0,6-5,6$ & $0,01-2,5$ & $0,008-0,9$ & $0,01-0,1$ \\
\hline \multirow{2}{*}{$\mathrm{Lu}$} & $0,4 \pm 0,02$ & $0,02 \pm 0,003$ & $0,01 \pm 0,002$ & $0,005 \pm 0,0002$ \\
\hline & $0,1-1,5$ & $0,002-0,5$ & $0,0004-0,9$ & $0,001-0,02$ \\
\hline \multirow{2}{*}{ Th } & $5,8 \pm 0,1$ & $0,2 \pm 0,02$ & $0,07 \pm 0,01$ & $0,01 \pm 0,001$ \\
\hline & $\overline{1,4-10,8}$ & $\overline{0,003-2,6}$ & $0,01-3,5$ & $0,002-0,1$ \\
\hline \multirow{2}{*}{$\mathrm{U}$} & $2,3 \pm 0,1$ & $3,3 \pm 0,5$ & $0,2 \pm 0,01$ & $0,1 \pm 0,01$ \\
\hline & $\overline{0,2-9,4}$ & $\overline{0,02-66,4}$ & $\overline{0,005-3}$ & $\overline{0,001-2,5}$ \\
\hline $\mathrm{Th} / \mathrm{U}$ & 2,5 & 0,05 & 0,4 & 0,1 \\
\hline $\mathrm{La} / \mathrm{Ce}$ & 0,5 & 0,3 & 0,8 & 0,7 \\
\hline $\mathrm{La} / \mathrm{Yb}$ & 9,9 & 7,1 & 9,6 & 1,9 \\
\hline $\mathrm{La}+\mathrm{Ce} / \mathrm{Sm}+\mathrm{Eu}$ & 12 & 8,7 & 5,5 & 7,0 \\
\hline $\mathrm{La}+\mathrm{Ce} / \mathrm{Yb}+\mathrm{Lu}$ & 25 & 28 & 16 & 4,2 \\
\hline
\end{tabular}

Примечание: в скобках - количество проб; числитель - среднее арифметическое 士стандартная ошибка, знаменатель -минимальное и максимальное значение.

Note: amount of samples is given in brackets; the arithmetic average \pm standard error is given in the numerator, the min-max content is given in the denominator. 


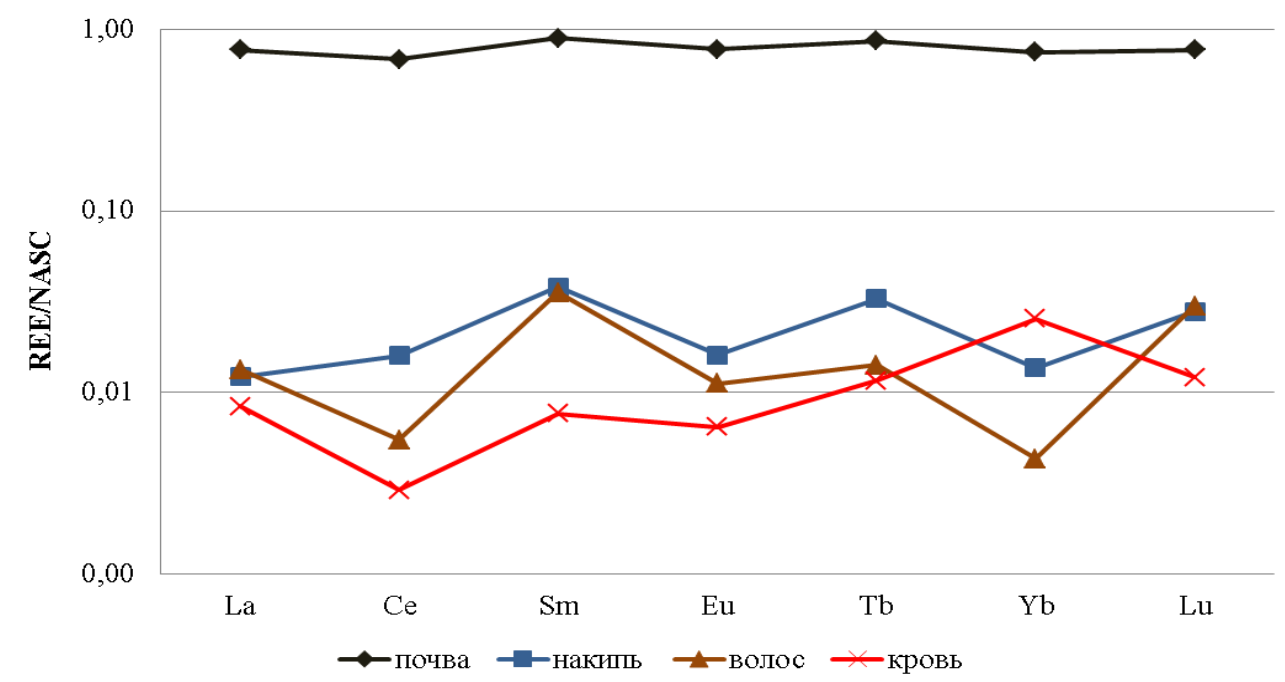

Pис. 2. Нормированное на NASC содержание РЗЭ в компонентах природной среды и биосубстратах человека территории Томской области

Fig. 2. NASC-normalized REE patterns of mean in components of the environment and human biosubstrates of Tomsk Region

Очевидно, что на формирование среднего элементного состава компонентов природной среды существенное влияние оказывают локальные геохимические факторы. При анализе компонентов природной среды на значительных расстояниях очевидным является факт их изменения в зависимости от смены геохимической обстановки. Для территории Томской области характерным является изменение климатических, ландшафтных и геохимических условий.

Информативным является изучение соотношений радиоактивных элементов и суммы РЗЭ. Нами была

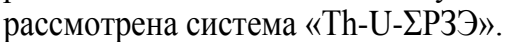

Почвы в рамках административных районов Томской области характеризуются однородным расположением в системе «Th-U- इP3Э» (рис. 3, a). Однако ряд населенных пунктов Асиновского и Тегульдетского районов характеризуется повышенным содержанием U.

Для солевых отложений природных пресных вод (накипи) (рис. 3, b) для большей части населённых пунктов характерна РЗЭ специализация. Для некоторых населенных пунктов Зырянского, Тегульдетского и Томского районов отмечается повышенное содержание U в накипи питьевых вод. Ранее было отмечено, что высокие значения обусловлены влиянием Яйского месторождения бурых углей, обогащенных РЗЭ и U [59].

В волосах жителей Томской области распределение крайне неоднородное, но для большинства административных районов характерна U-P3Э специализация (рис. 3, c). На этом фоне выделяются населенные пункты Томского района (Наумовка, Георгиевка, Козюлино, Самусь, Моряковский Затон, Орловка), где отмечается повышенное содержание Тh. Следует отметить промежуточное положение населенных пунктов Александровского и Каргасокского районов, основных нефтегазовых центров Томской области, в изученной системе.

Кровь жителей Томской области характеризуется $\mathrm{U}$ специализацией (рис. 3, d). Для отдельных населенных пунктов области отмечается повышенное содержание РЗЭ.

Для районирования территории по уровням содержания РЗЭ и радиоактивных элементов нами был применен подход, охватывающий большие по площади территории в рамках междуречий Оби и ее крупных притоков. Были выделены три территории: ОбьВасюганское, Обь-Чулымское и Кеть-Чулымское междуречья. Для данных территорий был применен анализ частоты встречаемости аномальных содержаний РЗЭ и радиоактивных элементов.

Анализ содержания $\mathrm{Sm}$ (рис. 4, $a$ ) в почвах и волоcax показывает, что максимум приходится на ОбьВасюганское междуречье и уменьшается в ОбьЧулымском и Кеть-Чулымском междуречьях. Анализ концентраций $\mathrm{U}$ (рис. $4, b)$ в накипи и крови показал, что больше всего U приходится на Обь-Чулымское междуречье с уменьшением в Кеть-Чулымском и Обь-Васюганском.

В целом на основе данного подхода было проведено районирование территории Томской области с выявлением специфики, характерной для каждого из междуречий в комплексе изученных компонентов (рис. 5). Обь-Чулымское междуречье характеризуется MREE-HREE-Th-U специализацией. Для КетьЧулымского междуречья отмечается HREE-La-Eu специализация. Для Обь-Васюганского междуречья специализация представлена MREE-La. 

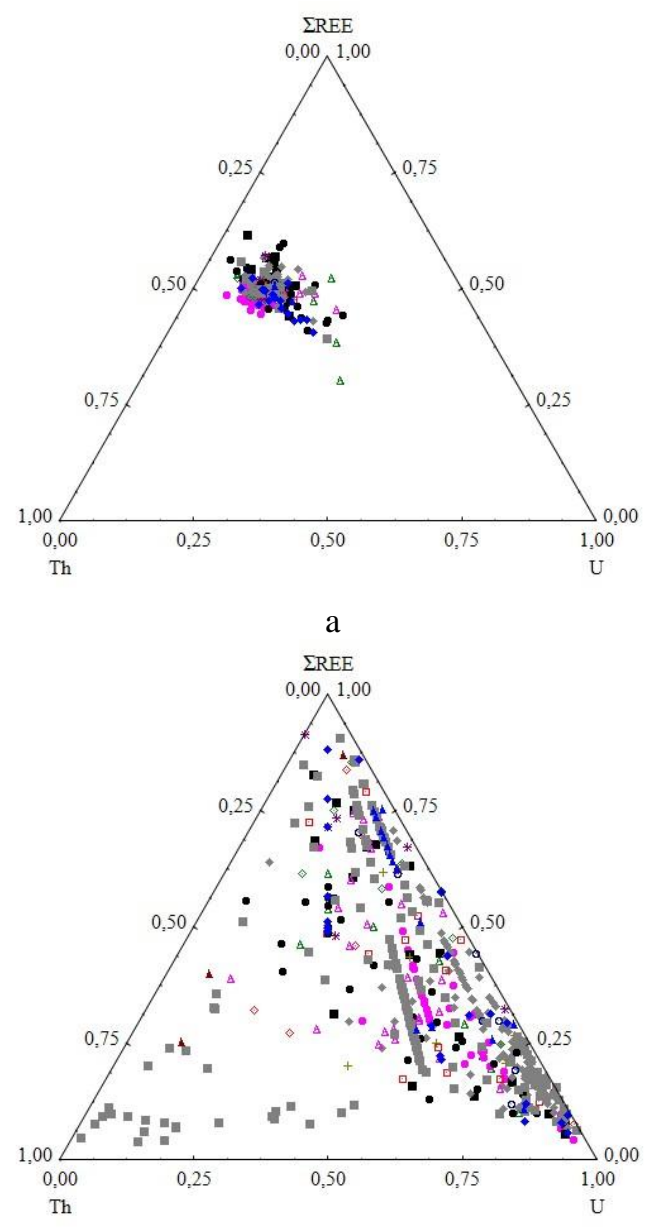

c

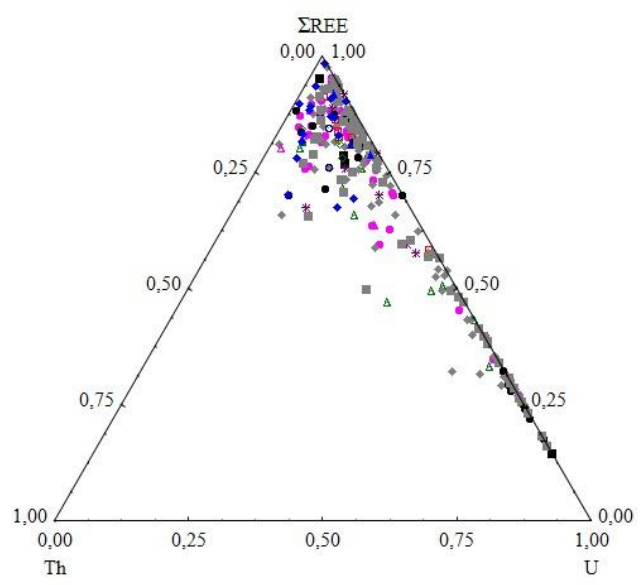

b

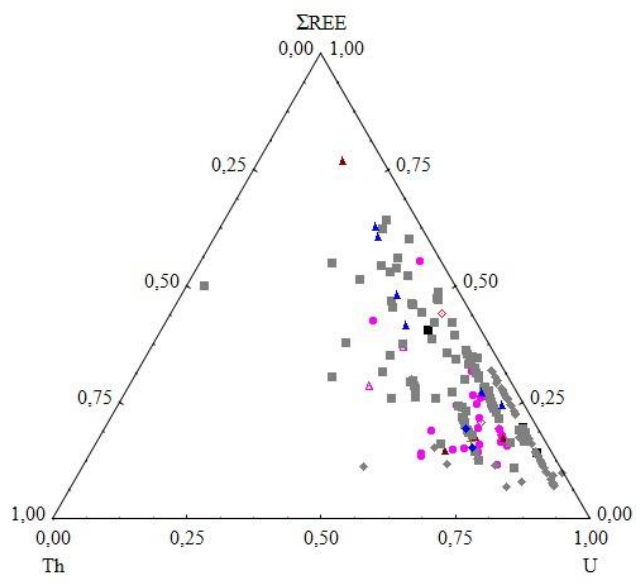

d

\section{$\circ 9 ; \quad \square 10 ; \diamond 11 ; \Delta 12 ; \bullet 13 ; \quad 14 ; \bullet 15 ; \wedge 16$}

Pис. 3. Тройная диаграмма соотношения содержаний Th, U и суммы РЗЭ в почве (а), солевых отложениях природных пресных вод (накипи) (b), волосах жителей (c), крови жителей (d) населенных пунктов районов Томской области: 1 - Александровский; 2 - Асиновский; 3 - Бакчарский; 4 - Верхнекетский; 5 - Зырянский; 6 - Каргасокский; 7 - Кожевниковский; 8 - Колпашевский; 9 - Кривошеинский; 10 - Молчановский; 11 - Парабельский; 12 - Первомайский; 13 - Тегульдетский; 14 - Томский; 15 - Чаинский; 16 -Шегарский

Fig. 3. Ternary diagram of Th, U contents, sum of REE in the soil (a), salt sediment of water (b), hair of residents (c), blood of residents of Tomsk region: 1 -Aleksandrovsky; 2 -Asinovsky; 3 - Bakcharsky; 4 - Verkhneketsky; 5 -Zyryansky; 6 - Kargasoksky; 7 - Kozhevnikovsky; 8 -Kolpashevsky; 9 - Krivosheinsky; 10 - Molchanovsky; 11 - Parabelsky; 12 - Pervomaysky; 13 - Teguldetsky; 14 - Tomsky; 15 - Chainsky; 16-Shegarsky

Sm

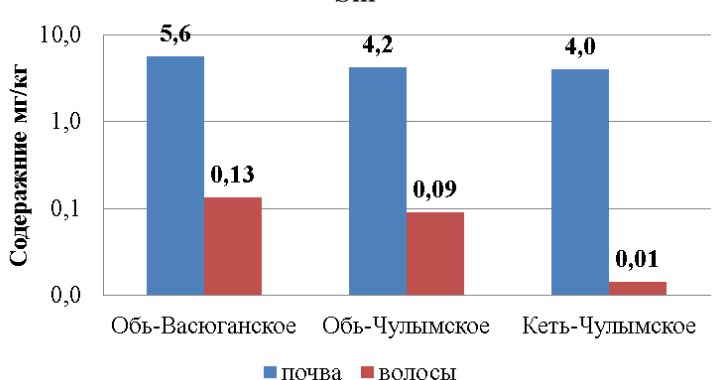

a

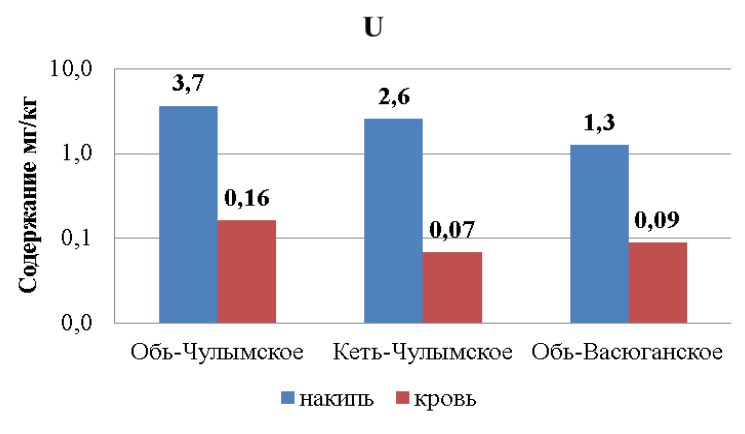

$\mathrm{b}$

Рис. 4. а) содержание Sт в почве и волосах жителей; b) содержание U в солевых отложениях питьевых вод (накипи) и крови жителей Томской области

Fig. 4. a) Sm content in soil and hair of residents; b) U content in salt deposits of water and blood of residents of Tomsk region 


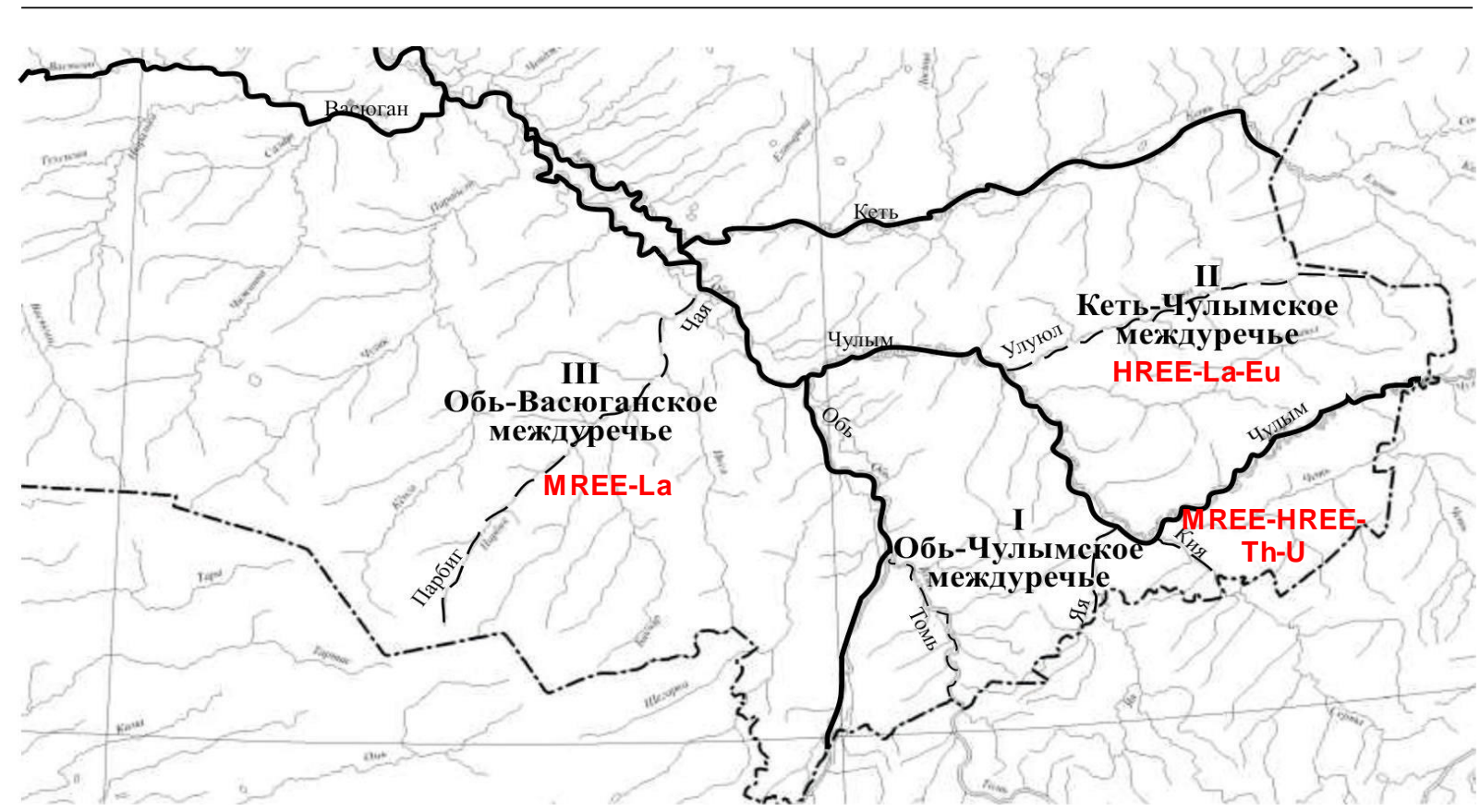

Pис. 5. Карта-схема геохимической специализачии территорий юга и юго-востока Томской области. Примечание: карта-схема основа на частоте встречаемости аномальных содержаний ( $x \geq+3 S)$ РЗЭ и радиоактивных элементов в компонентах природной среды; $x$-среднее арифметическое, $S$ - среднее квадратичное отклонение

Fig. 5. Map of geochemical specialization of the territories of the south and southeast of the Tomsk region. Note: the map is based on the frequency of occurrence of anomalous contents ( $x \geq+3 S)$ of REE and radioactive elements in the components of the natural environment; $x$ is the arithmetic average, $S$ is the standard deviation

\section{Выводы}

Установлены средние содержания радиоактивных (Th, U) и Р3Э (La, Ce, Sm, Eu, Tb, Yb, Lu) в четырех компонентах природной среды (почва, солевые отложения природных пресных вод (накипь), волосы и кровь человека) на территории Томской области.

Выявлено, что волосы и кровь характеризуются резким Се минимумом. В крови выявлен $\mathrm{Yb}$ максимум, что, возможно, связано с его нахождением в виде металлорганических комплексов.

Анализ распределения изученных элементов в системе «Th-U-इРЗЭ» позволил выявить территории, геохимически специализированные на изученные химические элементы.

\section{СПИСОК ЛИТЕРАТУРЫ}

1. Методические рекомендации по прогнозированию, поискам и перспективной оценке экзогенных месторождений иттрия и иттриевых лантаноидов / Н.А. Солодов, Ю.А. Грязнова, Т.Ю. Усова, Т.К. Прокофьева. - М.: Институт минералогии, геохимии и кристаллохимии редких элементов, 1991. -89 c.

2. Taylor S.R., McLennan S.M. The continental crust: its composition and evolution. - USA: Blackwell Scientific Publication, 1985. $-312 \mathrm{p}$.

3. Tyler G. Rare earth elements in soil and plant systems - a review // Plant Soil. - 2004. - V. 267. - P. 191-206.

4. Haxel G.B. Ultrapotassic mafic dikes and rare earth element- and barium-rich carbonatite at Mountain Pass, Mojave Desert, southern California; summary and field trip localities. - Reston, Virginia, 2005. - $56 \mathrm{p}$.

5. Oddo G. Die Molekularstruktur der radioaktiven Atome // Zeitschrift für Anorganische Chemie. - 1914. - V. 87. - P. 253-268.

6. Harkins W.D. The evolution of the elements and the stability of complex atoms. I. A new periodic system which shows a relation between the abundance of the elements and the structure of the
Анализ частоты встречаемости аномальных содержаний РЗЭ и радиоактивных элементов в компонентах природной среды позволил дифференцировать территорию юга и юго-востока Томской области по крупным междуречьям Оби и ее притоков и выявить геохимическую специализацию выделенных районов.

Таким образом, содержание и соотношение изученных элементов являются информативными индикаторными показателями, однако следует учитывать специфику каждого изучаемого компонента природной среды.

Исследование выполнено при финансовой поддержке РФФИ в рамках научного проекта № 19-35-90061

Авторы благодарят к.г.-м.н. Т.А. Монголину за предоставление части проб накипи для исследований.

nuclei of atoms // Journal of the American Chemical Society. 1917. - V. 39. - Iss. 5. - P. 856-879.

7. Барашков Г.К. Медицинская бионеорганика. Основы. Аналитика. Клиника. - М.: Бином, 2011. - 512 с.

8. Sources, behaviour, and environmental and human health risks of high-technology rare earth elements as emerging contaminants / W. Gwenzi, L. Mangori, C. Danha, N. Chaukura, N. Dunjana, E. Sanganyado // Science of the Total Environment. - 2018. V. 636. - P. 299-313.

9. Brioschi L. Transfert des terres rares à l'interface géosphère biosphère Répartition, transfert sol-végétation, et effet sur la physiologie des plantes: Thèse présentée pour l'obtention du titre de Docteur Spécialité. - Besançon, 2012. - 195 p.

10. Evaluating rare earth element availability: a case with revolutionary demand from clean technologies. Environ / E. Alonso, A.M. Sherman, T.J. Wallington, M.P. Everson, F.R. Field, R. Roth, R.E. Kirchain // Sci. Technol. - 2012. - V. 46. - Iss. 6. - P. 3406-3414.

11. Rare earths statistics and information // United States Geological Survey. - 2012. URL: http://minerals.usgs.gov/minerals/pubs/ commodity/rare earths (дата обращения 20.12.2018). 
12. Zdzisław M. Migaszewski, Gałuszka A. The characteristics, occurrence, and geochemical behavior of rare earth elements in the environment: a review // Critical Reviews in Environmental Science and Technology. - 2015. - V. 45. - Iss. 5. - P. 429-471.

13. Distribution and fractionation of the rare earth elements in Brazilian soils / H. de Sá Paye, J.W.V. de Mello, G.R.L. de Magalhães Mascarenhas, M. Gasparon // Journal of Geochemical Exploration. - 2016. - V. 161. - P. 27-41.

14. Inputs of rare earth elements in Brazilian agricultural soils via Pcontaining fertilizers and soil correctives / F.B.V. Silva, C.W.A. Nascimento, A.M. Alvarez, P.R.M. Araujo // Journal of Environmental Management. - 2019. - V. 232. - P. 90-96.

15. Determination of 16 heavy metal elements and 16 rare earth elements in Ya'an tibet tea by ICP-MS / P.W. Li, J.H. Li, S.X. Chen, X.L. Meng // IOP Conf. Series: Materials Science and Engineering. - 2018. - V. 423. - P. 1-7.

16. Zaremotlagh S., Hezarkhani A. A geochemical modeling to predict the different concentrations of REE and their hidden patterns using several supervised learning methods: Choghart iron deposit, Bafq, Iran // Journal of Geochemical Exploration. - 2016. - V. 165. P. $35-48$.

17. Decrée S., Pourret O., Baele J-M. Rare earth element fractionation in heterogenite $(\mathrm{CoOOH})$ : implication for cobalt oxidized ore in the Katanga Copperbelt (Democratic Republic of Congo) // Journal of Geochemical Exploration. - 2015. - V. 159. - P. 290301.

18. Rare earth elements in French stream waters - revisiting the geochemical continental cycle using FOREGS dataset / R. Armand C. Cherubini, J. Tuduri, N. Pastore, O. Pourret // Journal of Geochemical Exploration. - 2015. - V. 157. - P. 132-142.

19. Panichev A.M. Rare earth elements: review of medical and biological properties and their abundance in the rock materials and mineralized spring waters in the context of animal and human geophagia reasons evaluation // Achievements in the Life Sciences. -2015. - V. 9. - P. 95-103.

20. Киселева Д.В. Особенности состава, структуры и свойств ряда фосфатных и карбонатных биоминеральных образований: автореф. дис. ... канд. геол.-минерал. наук. - Екатеринбург, 2007. $-29 \mathrm{c}$.

21. Балашов Ю.А. Геохимия редкоземельных элементов. - М.: Наука, 1976. - 258 с

22. Распределение редких земель в литосфере и космосе / Л.А. Хэскин, Ф.А. Фрей, Р.А. Шмитт, Р.Х. Смит. - М.: Мир, 1968. $-186 \mathrm{c}$.

23. Минеев Д.А. Лантаноиды в рудах редкоземельных и комплексных месторождений. - М.: Наука, 1974. - 240 с.

24. Арбузов С.И., Рихванов Л.П. Геохимия радиоактивных элементов. 3-е изд. испр. и доп. - Томск: Изд-во ТПУ, 2011. $300 \mathrm{c}$.

25. The interaction of actinide and lanthanide ions with hemoglobin and its relevance to human and environmental toxicology / A. Kumar, M. Ali, S.N. Raghumani, P. Gaikwad, M. Kumar, B.N. Bimalendu, N.P. Badri // Journal of Hazardous Materials. 2016. - V. 301. - P. 281-293

26. Rare earth elements and select actinoids in the Canadian House Dust Study / P.E. Rasmussen, C. Levesque, M. Chenier, H.D. Gardner // Indoor Air. - 2017. - V. 27. - P. 965-976.

27. Очерки геохимии человека: монография / Н.В. Барановская, Л.П. Рихванов, Т.Н. Игнатова и др. - Томск: Изд-во ТПУ, 2015. $-378 \mathrm{c}$.

28. Гринвуд Н., Эрншо А. Химия элементов: в 2 т. / пер. с англ. М.: Бином. Лаборатория знаний, 2008. - Т. 2. - 670 с.

29. Алексеенко В.А. Геоэкология: экологическая геохимия. изд. 2-е, перераб. - Ростов-на-Дону: Изд-во Феникс, 2017. - 685 с.

30. Виноградов А.П. Геохимия живого вещества. - Л.: АН СССР. $-1932 .-67 \mathrm{c}$

31. Hoffman J. U in human thyroid gland and dog testicule and pancreas // Naturwissenschaften. - 1942. - № 30 - P. 279-280.

32. Hoffman J. Urankonzentration der in Beziehung stehenden Organe: Hirnanhang, Schilddrsse, Keimdrsen, Nebenniere und Bauchspeicheldrsse // Biochemische Zeitschrift. - 1943. - V. 315 - № 1-2. - P. 26-30.

33. Hoffman J. Bioelement Uran im Pflanzen - und Tierreich sowie im menschlichen Organismus // Biochemische Zeitschrift. 1943. - V. 313. - № 5-6. - P. 377-387.
34. Добровольский В.В. Геохимическое землеведение. - М.: Владос, 2008. - 207 c.

35. Uranium mining wastes: the use of the Fish Embryo acute Toxicity Test (FET) test to evaluate toxicity and risk of environmental discharge / J. Lourenço, S. Marques, F.P. Carvalho, J. Oliveira, M. Malta, M. Santos, F. Gonçalves, R. Pereira, S. Mendo // Science of the Total Environment. - 2017. - V. 605-606. - P. 391-404.

36. Ковалевский А.Л., Ковалевская О.М. Биогеохимия урановых месторождений и методические основы их поиска. - Новосибирск: Гео, 2010. - 362 с.

37. Влияние техногенеза на формирование элементного состава волос детского населения / Д.В. Наркович (Швецова), Н.В. Барановская, Е.В. Агеева (Коваль), Н.П. Корогод // Известия Томского политехнического университета. Инжиниринг георесурсов. - 2016. - Т. 327. - № 8. - С. 116-128.

38. Дубинин А. В. Геохимия редкоземельных элементов в океане. - М.: Наука, 2006. - 339 с.

39. Редкоземельные элементы ( $\mathrm{La}, \mathrm{Ce}, \mathrm{Sm}, \mathrm{Eu}, \mathrm{Tb}, \mathrm{Yb}, \mathrm{Lu})$ в углях Северной Азии (Сибирь, российский Дальний Восток, Северный Китай, Монголия, Казахстан) / С.И. Арбузов, И.Ю. Чекрыжов, С. Юйчжуан, Ж. Цунлян, В.С. Машенькин, С.С. Ильенок, В.В. Иванов, М.Г. Блохин, Н.В. Зарубина // Геосферные исследования. - 2017. - № 4. - С. 6-27.

40. Редкоземельные элементы в атмосферных осадках на территории г. Благовещенска / Радомская В.И., Юсупов Д.В., Павлова Л.М. // Геохимия. - 2018. - № 2. - С. 197-206.

41. Toxicity of cerium and thorium on Daphnia magna / Y. Ma, J. Wang, C. Peng, Y. Ding, X. He, P. Zhang, N. Li, T. Lan, D. Wang, Z. Zhang, F. Sun, H. Liao, Z. Zhang // Ecotoxicology and Environmental Safety. - 2016. - V. 134. - P. 226-232.

42. Rare-earth nanoparticle-induced cytotoxicity on spatial cognition memory of mouse brain / C-H. Lin, G-F. Liu, J. Chen, Y. Chen, R-H. Lin, H-X. He, J-P. Chen // Chinese Medical Journal. 2017. - V. 130. - Iss. 22. - P. 1591-1597.

43. Potential clinical risk of inflammation and toxicity from rare-earth nanoparticles in mice / J-P. Chen, S-S. Shi, G-F. Liu, Y. Chen, S-S. Zheng, X-B. Wang, R-H. Lin, H-X. He, C-H. Lin // Chinese Medical Journal. - 2018. - V. 131. - P. 1591-1597.

44. Soil pollution and toxicity in an area affected by emissions from a bauxite $\mathrm{T}$ processing plant and a power plant in Gardanne (southern France) / R. Oral, G. Pagano, A. Siciliano, M. Toscanesi, M. Gravina, A. di Nunzio, A. Palumbo, P.J. Thomas, F. Tommasi, P. Buric, D.M. Lyons, M. Guida, M. Trifuoggi // Ecotoxicology and Environmental Safety. - 2019. - V. 170. - P. 55-61.

45. Toxicity assay of lanthanum and cerium in solutions and soil / A. Kotelnikova, I. Fastovets, O. Rogova, D.S. Volkov, V. Stolbova // Ecotoxicology and Environmental Safety. - 2019. V. $167 .-$ P. $20-28$.

46. Арбузов С.И. Геохимия редких элементов в углях Центральной Сибири: автореф. дис. ... д-ра геол.-минерал. наук. Томск, 2005. $-48 \mathrm{c}$.

47. Циркон-ильменитовые россыпные месторождения - как потенциальный источник развития Западно-Сибирского региона / Л.П. Рихванов, С.С. Кропанин, С.А. Бабенко, А.И. Соловьев, В.М. Советов, Т.Ю. Усова, М.А. Полякова. - Кемерово: Издво ООО «Сарс», 2001. $-214 \mathrm{c}$.

48. ГОСТ 17.4.3.01 - 83. Охрана природы. Почвы. Общие требования к охране почв. - М.: Изд-во «Стандартинформ», 1984. $4 \mathrm{c}$.

49. ГОСТ 17.4.4.02-84. Охрана природы. Почвы. Методы отбора и подготовки проб для химического, бактериологического, гельминтологического анализа. - М.: Изд-во «Стандартинформ», 1986. $-7 \mathrm{c}$.

50. Комплексная эколого-геохимическая оценка техногенного загрязнения окружающей природной среды / Э.К. Буренков, Л.Н. Гинзбург, Н.К. Грибанова и др. - М.: Изд-во «ПРИМАПРЕСС», 1997. $-72 \mathrm{c.}$

51. Способ определения участков загрязнения ураном окружающей среды: пат. 2298212 Рос. Федерация. № 2005120840; заявл. 04.07.05; опубл. 27.04.07, Бюл. № 12. - 6 c.

52. Element analysis of biological materials. Current problems and techniques with special reference to trace. Appendix II. Technical reports series. - Vienna: IAEA, 1980. - V. 197. - P. 351-367.

53. Перельман А.И., Касимов Н.С. Геохимия ландшафта. - М.: Астрея-2000, 1999. - 610 с. 
54. Евсеева Л.С., Перельман А.И., Иванов К.Е. Геохимия урана в зоне гипергенеза. 2-е изд. - М.: Атомиздат, 1975. - 240 с.

55. Рихванов Л.П. Радиоактивность и радиоактивные элементы в гидросфере // Радиоактивность и радиоактивные элементы в среде обитания человека: материалы V Международной конференции. - Томск, 13-16 сентября 2016. - Томск: Изд-во ТПУ, 2016. - С. 549-557.

56. The European shale: an improved data set for normalisation of rare earth element and yttrium concentrations in environmental and biological samples from Europe / M. Bau, K. Schmidt, A. Pack, V. Bendel, D. Kraemer // Applied Geochemistry. - 2018. V. 90. - P. 142-149.

\section{Информация об авторах}

Барановская Н.B., доктор биологических наук, профессор отделения геологии Инженерной школы природных ресурсов Национального исследовательского Томского политехнического университета.

Azеева E.B., аспирант отделения геологии Инженерной школы природных ресурсов Национального исследовательского Томского политехнического университета.

Соктоев Б.P., кандидат геолого-минералогических наук, старший преподаватель отделения геологии Инженерной школы природных ресурсов Национального исследовательского Томского политехнического университета.

Наркович Д.В., кандидат геолого-минералогических наук, старший преподаватель отделения геологии Инженерной школы природных ресурсов Национального исследовательского Томского политехнического университета.

Денисова О.А., кандидат медицинских наук, ассистент кафедры госпитальной терапии с курсом физической реабилитации и спортивной медицины Сибирского государственного медицинского университета Министерства здравоохранения Российской Федерации.

Матковская T.B., доктор медицинских наук, заслуженный врач РФ, профессор кафедры детских болезней Сибирского государственного медицинского университета Министерства здравоохранения Российской Федерации. 
UDC 550.422:546.7:504.064(571.16)

\title{
RARE EARTH AND RADIOACTIVE (TH, U) ELEMENTS IN THE COMPONENTS OF THE ENVIRONMENT ON THE TERRITORY OF TOMSK REGION
}

\author{
Natalia V. Baranovskaya'1, \\ nata@tpu.ru \\ Elena V. Ageeva ${ }^{1}$, \\ ev_ageeva@mail.ru \\ Bulat R. Soktoev 1 , \\ bulatsoktoev@tpu.ru \\ Dina V. Narkovich ${ }^{1}$, \\ shvezova_d@mail.ru \\ Olga A. Denisova², \\ oadeni@yandex.ru \\ Tamara V. Matkovskaya², \\ matkovskay@inbox.ru \\ 1 National Research Tomsk Polytechnic University, \\ 30, Lenin avenue, Tomsk, 634050, Russia. \\ 2 Siberian State Medical University, \\ 2, Moskovsky trakt, Tomsk, 634050, Russia.
}

The relevance of the research is caused by the need to consider the correlations of radioactive and rare earth elements from the point of view of their high indicator role in the complex of components of the environment in local territories characterized by different natural and man-made conditions and zoning of the territory based on biogeochemical indicators.

The aim of the research is to consider the correlations of radioactive and rare earth elements in the complex of the components of the environment in the territory of the Tomsk region, characterized by various natural and man-made environments.

Methods. The main method of the research is instrumental neutron activation analysis, which was carried out on the basis of a research nuclear reactor of the National Research Tomsk Polytechnic University. The content of two radioactive - thorium and uranium, as well as seven rare earth ( $L a, C e, S m, E u, T b, Y b$, Lu) elements - was determined.

Results. The authors have studied the content of rare earth and radioactive elements in four simultaneously selected and studied components of the environment of Tomsk region: soil, salt sediment of water, human blood and hair. The content of the studied elements is maximal for soils and for salt sediment of water, and significantly lower in human biosubstrates. Human hair and blood as living tissues are characterized by a sharp cerium minimum. The ytterbium maximum was detected in the blood, which may be related to its presence in the form of organometallic complexes. According to the frequency of occurrence of the anomalous contents of rare earth and radioactive elements, zoning of Tomsk region was carried out for significant tributaries of the Ob river in all studied components.

\section{Key words:}

Rare earth and radioactive elements, components of the environment, indicator, ratio of the elements, Tomsk region, biogeochemical zoning of the territory.

The reported study was funded by RFBR, project number 19-35-90061.

The authors appreciate T.A. Mongolina, Cand. Sc., for a part of salt sediment of water samples for the research.

\section{REFERENCES}

1. Solodov N.A., Gryaznova Yu.A., Usova T.Yu., Prokofyeva T.K. Metodicheskie rekomendatsii po prognozirovaniyu, poiskam perspektivnoy otsenke ekzogennykh mestorozhdeniy ittriya ittrievykh lantanoidov [Methodical recommendations on forecasting, searching and prospective evaluation of exogenous yttrium and yttrium lanthanide deposits]. Mosocw, Institute of mineralogy, geochemistry and crystal chemistry of rare elements Publ., 1991. 89 p.

2. Taylor S.R., McLennan S.M. The continental crust: its composition and evolution. USA, Blackwell Scientific Publication, 1985. $312 \mathrm{p}$

3. Tyler G. Rare earth elements in soil and plant systems - a review. Plant Soil, 2004, vol. 267, pp. 191-206.
4. Haxel G.B. Ultrapotassic mafic dikes and rare earth element- and barium-rich carbonatite at Mountain Pass, Mojave Desert, southern California; summary and field trip localities. Reston, Virginia, 2005. pp. 56.

5. Oddo G. Die Molekularstruktur der radioaktiven Atome [The molecular structure of the radioactive atoms]. Zeitschrift für Anorganische Chemie, 1914, vol. 87, pp. 253-268.

6. Harkins W.D. The evolution of the elements and the stability of complex atoms. I. A new periodic system which shows a relation between the abundance of the elements and the structure of the nuclei of atoms. Journal of the American Chemical Society, 1917, vol. 39, Iss. 5, pp. 856-879.

7. Barashkov G.K. Meditsinskaya bioneorganika. Osnovy, analitika, klinika [Medical Bioinorganics. Fundamentals, analytics, clinic]. Moscow, Binom Publ., 2011. 512 p. 
8. Gwenzi W., Mangori L., Danha C., Chaukura N., Dunjana N., Sanganyado E. Sources, behaviour, and environmental and human health risks of high-technology rare earth elements as emerging contaminants. Science of the Total Environment, 2018, vol. 636, pp. 299-313.

9. Brioschi L. Transfert des terres rares à l'interface géosphère biosphère Répartition, transfert sol-végétation, et effet sur la physiologie des plantes: thèse présentée pour l'obtention du titre de Docteur Spécialité [Transfer of rare earth elements on the border of the geosphere and biosphere Distribution, transfer in the soil-plant system and the effect on plant physiology. Dr. Sc. Diss.]. Besancon, 2012. 195 p.

10. Alonso E., Sherman A.M., Wallington T.J., Everson M.P., Field F.R., Roth R., Kirchain R.E. Evaluating rare earth element availability: A case with revolutionary demand from clean technologies. Environ. Sci. Technol., 2012, vol. 46, Iss. 6, pp. 3406-3414.

11. Rare earths statistics and information. United States Geological Survey, 2012. Available at: http://minerals.usgs.gov/minerals/ pubs/commodity/rare_earths (accessed 20 December 2018).

12. Zdzisław M., Migaszewskia, Gałuszkaa A. The characteristics, occurrence, and geochemical behavior of rare earth elements in the environment: a review. Critical Reviews in Environmental Science and Technology, 2015, vol. 45, Iss. 5, pp. 429-471.

13. De Sá Paye H., De Mello J.W.V., De Magalhães Mascarenhas G.R.L., Gasparon M. Distribution and fractionation of the rare earth elements in Brazilian soils. Journal of Geochemical Exploration, 2016, vol. 161, pp. 27-41.

14. Silva F.B.V., Nascimento C.W.A., Alvarez A.M., Araujo P.R.M Inputs of rare earth elements in Brazilian agricultural soils via Pcontaining fertilizers and soil correctives. Journal of Environmental Management, 2019, vol. 232, pp. 90-96.

15. Li P.W., Li J.H., Chen S.X., Meng X.L. Determination of 16 heavy metal elements and 16 rare earth elements in Ya'an tibet tea by ICP-MS. IOP Conf. Series: Materials Science and Engineering, 2018, vol. 423, pp. 1-7.

16. Zaremotlagh S., Hezarkhani A. A geochemical modeling to predict the different concentrations of REE and their hidden patterns using several supervised learning methods: Choghart iron deposit, Bafq, Iran. Journal of Geochemical Exploration, 2016, vol. 165, pp. 35-48.

17. Decrée S., Pourret O., Baele J-M. Rare earth element fractionation in heterogenite $(\mathrm{CoOOH})$ : implication for cobalt oxidized ore in the Katanga Copperbelt (Democratic Republic of Congo). Journal of Geochemical Exploration, 2015, vol. 159, pp. 290-301.

18. Armand R., Cherubini C., Tuduri J., Pastore N., Pourret O. Rare earth elements in French stream waters - Revisiting the geochemical continental cycle using FOREGS dataset. Journal of Geochemical Exploration, 2015, vol. 157, pp. 132-142.

19. Panichev A.M. Rare earth elements: review of medical and biological properties and their abundance in the rock materials and mineralized spring waters in the context of animal and human geophagia reasons evaluation. Achievements in the Life Sciences, 2015 , vol. 9, pp. 95-103.

20. Kiseleva D.V. Osobennosti sostava, struktury i svoystv ryada fosfatnykh $i$ karbonatnykh biomineralnykh obrazovaniy. Avtoreferat Dis. Kand. nauk [Specific aspects of structure and features of number of phosphate and carbonate biomineral formations. Cand. Diss. Abstract]. Ekaterinburg, 2007. 29 p.

21. Balashov Yu.A. Geokhimiya redkozemelnykh elementov [Geochemistry of rare earth elements]. Mosocw, Nauka Publ., 1976. $258 \mathrm{p}$

22. Kheskin L.A., Frey F.A., Shmitt R.A., Smit R.Kh. Raspredelenie redkikh zemel v litosfere $i$ kosmose [Meteoritic, solar and terrestrial rare-earth distribution]. Mosocw, Mir Publ., 1968. 186 p.

23. Mineev D.A. Lantanoidy $v$ rudakh redkozemelnykh $i$ kompleksnykh mestorozhdeniy [Lanthanides in ores of rare earth and complex deposits]. Moscow, Nauka Publ., 1974. 240 p.

24. Arbuzov S.I., Rihvanov L.P. Geokhimiya radioaktivnykh elementov [Geochemistry of radioactive elements]. Tomsk, TPU Publ. house, 2011. 300 p.

25. Kumar A., Ali M., Raghumani S. Ningthoujam, Gaikwad P., Kumar M., Bimalendu B. Nath, Badri N. Pandeya. The interaction of actinide and lanthanide ions with hemoglobin and its relevance to human and environmental toxicology. Journal of Hazardous Materials, 2016, vol. 301, pp. 281-293.
26. Rasmussen P.E., Levesque C., Chenier M., Gardner H.D. Rare earth elements and select actinoids in the Canadian House Dust Study. Indoor Air, 2017, vol. 27, pp. 965-976.

27. Baranovskaya. N.V., Rikhvanov L.P., Ignatova T.N. Ocherki geokhimii cheloveka: monografiya [The human geochemistry essays: monograph]. Tomsk, TPU Publ., 2015. 378 p.

28. Grinvud N., Ernsho A. Khimiya elementov [Chemistry of elements]. Translated from English. Moscow, Binom. Laboratoriya znaniy Publ., 2008. Vol. 2, 670 p.

29. Alekseenko V.A. Geoekologiva: ekologicheskaya geokhimiya [Geoecology: ecological geochemistry]. Rostov-na-Donu, Feniks Publ., 2017. 685 p.

30. Vinogradov A.P. Geohimiya zhivogo veshchestva [Geochemistry of living matter]. Leningrad, AN SSSR, 1932. $67 \mathrm{p}$.

31. Hoffman J. U in human thyroid gland and dog testicule and pancreas. Naturwissenschaften, 1942 , no. 30, pp. 279-280.

32. Hoffman J. Urankonzentration der in Beziehung stehenden Organe: Hirnanhang, Schilddrsse, Keimdrsen, Nebenniere und Bauchspeicheldrsse. Biochemische Zeitschrift, 1943, vol. 315, no. 1-2, pp. 26-30.

33. Hoffman J. Bioelement Uran im Pflanzen - und Tierreich sowie im menschlichen Organismus [Bioelement uranium in the plant and animal kingdom and in the human organism]. Biochemische Zeitschrift, 1943, vol. 313, no. 5-6, pp. 377-387.

34. Dobrovolskiy V.V. Geokhimichsekoe zemlevedenie [Geochemical geography]. Mosocw, Vlados Publ., 2008. 207 p.

35. Lourenço J., Marques S., Carvalho F.P., Oliveira J., Malta M., Santos M., Gonçalves F., Pereira R., Mendo S. Uranium mining wastes: the use of the Fish Embryo acute Toxicity Test (FET) test to evaluate toxicity and risk of environmental discharge. Science of the Total Environment, 2017, vol. 605-606, pp. 391-404.

36. Kovalevskiy A.L., Kovalevskaya O.M. Biogeokhimiva uranovykh mestorozhdeniy $i$ metodicheskie osnovy ikh poiska [Biogeochemistry of uranium deposits and methodological fundamentals of their prospecting]. Novosibirsk, Geo Publ., 2010. $362 \mathrm{p}$.

37. Narkovich (Shvetsova) D.V., Baranovskaya N.V., Ageyeva (Koval) E.V., Korogod N.P. Influence of technogenesis on forming element composition of children's hair. Bulletin of the Tomsk Polytechnic University. Geo Assets Engineering, 2016, vol. 327, no. 8, pp. 116-128. In Rus.

38. Dubinin A.V. Geokhimiya redkozemelnykh elementov v okeane [Rare earth geochemistry in the ocean]. Moscow, Nauka Publ., 2006. 339 p.

39. Arbuzov S.I., Chekryzhov I.Yu., Yuychzhuan S., Tsunlyan Zh., Mashenkin V.S., Ilyenok S.S., Ivanov V.V., Blokhin M.G., Zarubina N.V. Rare-earth elements ( $\mathrm{La}, \mathrm{Ce}, \mathrm{Sm}, \mathrm{Eu}, \mathrm{Tb}, \mathrm{Yb}, \mathrm{Lu}$ ) in the coals of the North Asia (Siberia, Russian Far East, North China, Mongolia, Kazakhstan). Geosphere Research, 2017, no. 4, pp. 6-27. In Rus.

40. Radomskaya V.I., Yusupov D.V., Pavlova L.M. Rare-earth elements in the atmospheric precipitation of the city of Blagoveshchensk. Geochemistry International, 2018, no. 2, pp. 197-206. In Rus.

41. Ma Y., Wang J., Peng C., Ding Y., He X., Zhang P., Li N., Lan T., Wang D., Zhang Z., Sun F., Liao H., Zhang Z. Toxicity of cerium and thorium on Daphnia magna. Ecotoxicology and Environmental Safety, 2016, vol. 134, pp. 226-232.

42. Lin C-H., Liu G-F., Chen J., Chen Y., Lin R-H., He H-X., Chen J-P. Rare-earth Nanoparticle-induced Cytotoxicity on Spatial Cognition Memory of Mouse Brain. Chinese Medical Journal, 2017, vol. 130, Iss. 22, pp. 1591-1597.

43. Chen J-P., Shi S-S., Liu G-F., Chen Y., Zheng S-S., Wang X-B., Lin R-H., He H-X., Lin C-H. Potential clinical risk of inflammation and toxicity from rare-earth nanoparticles in mice. Chinese Medical Journal, 2018, vol. 131, pp. 1591-1597.

44. Oral R., Pagano G., Siciliano A., Toscanesi M., Gravina M., A. Di Nunzio, Palumbo A., Thomas P.J., Tommasi F., Buric P., Lyons D.M., Guida M., Trifuoggi M. Soil pollution and toxicity in an area affected by emissions from a bauxite $\mathrm{T}$ processing plant and a power plant in Gardanne (southern France). Ecotoxicology and Environmental Safety, 2019, vol. 170, pp. 55-61.

45. Kotelnikova A., Fastovets I., Rogova O., Volkov D.S., Stolbova V. Toxicity assay of lanthanum and cerium in solutions and soil. Ecotoxicology and Environmental Safety, 2019, vol. 167, pp. 20-28. 
46. Arbuzov S.I. Geokhimiya redkikh elementov $v$ uglyakh Tsentralnoy Sibiri. Avtoreferat Dis. Dokt. nauk [Rare elements geochemistry of Central Siberia coals. Dr. Diss. Abstract]. Tomsk, 2005. $48 \mathrm{p}$.

47. Rikhvanov L.P., Kropanin S.S., Babenko S.A., Solovyev A.I., Sovetov V.M., Usova T.Yu., Polyakova M.A. Tsirkon-ilmenitovye rossypnye mestorozhdeniya - kak potentsialny istochnik razvitiya Zapadno-Sibirskogo regiona [Zircon-ilmenite placer deposits as a potential source for Western Siberian region development Editors]. Kemerovo, 2001.214 p.

48. GOST 17.4.3.01-83. Okhrana prirody. Pochvy. Obshchie trebovaniya $k$ okhrane pochv [Nature protection. Soils. General requirements for sampling]. Moscow, StandardInform Publ., 1984. $4 \mathrm{p}$.

49. GOST 17.4.4.02-83. Okhrana prirody. Pochvy. Metody otbora $i$ podgotovki prob dlya khimicheskogo, bakteriologicheskogo, gelmintologicheskogo analiza [Nature protection. Soils. Methods for sampling and preparation of soil for chemical, bacteriological, helmintological analysis]. Moscow, StandardInform Publ.,1986. $7 \mathrm{p}$.

50. Burenkov E.K., Ginzburg L.N., Gribanova N.K. Kompleksnaya ekologo-geokhimicheskaya otsenka tekhnogennogo zagryazneniya okruzhayushchey prirodnoy sredy [Complex eco-geochemical evaluation of anthropogenic pollution of the environment]. Moscow, PRIMA-PRESS, $1997.72 \mathrm{p}$.

51. Baranovskaya. N.V., Rikhvanov L.P., Yazikov E.G., Yankovich E.P. Sposob opredeleniya uchastkov zagryazneniya uranom okruzhayushchey sredy [Method for determination of areas in the environment polluted with uranium]. Patent RF, no. 2005120840, 2007.

52. Element analysis of biological materials. Current problems and techniques with special reference to trace elements. Appendix II. Technical reports series. Vienna, IAEA, 1980. Vol. 197, pp. 351-367.
53. Perelman A.I., Kasimov N.S. Geokhimiya landshafta [Geochemistry of landscape]. Moscow, Astreya-2000 Publ., 1999. $610 \mathrm{p}$.

54. Evseeva L.S., Perelman A.I., Ivanov K.E. Geokhimiya urana v zone gipergeneza [Uranium geochemistry in the hypergenesis zone]. Moscow, Atomizdat Publ., 1975. 240 p.

55. Rikhvanov L.P. Radioaktivnost i radioaktivnye elementy v gidrosfere [Radioactivity and radioactive elements in the hydrosphere]. Radioaktivnost $i$ radioaktivnye element $v$ srede obitaniya cheloveka. Materialy V Mezhdunarodnoy konferentsii [Radioactivity and radioactive elements in environment. Proc. of $\mathrm{V}$ international conference]. Tomsk, 13-16 September, 2016. Tomsk, TPU Publ. house, 2016. pp. 549-557.

56. Bau M., Schmidt K., Pack A., Bendel V., Kraemer D. The European shale: an improved data set for normalisation of rare earth element and yttrium concentrations in environmental and biological samples from Europe. Applied Geochemistry, 2018, vol. 90, pp. 142-149.

57. Zanin Yu.N., Zamirailova A.G., Eder V.G., Krasavchikov V.O. Redkozemelnye elementy $\mathrm{v}$ bazhenovskoy svite ZapadnoSibirskogo osadochnogo basseyna [Rare earth elements in the Bazhenov Formation of the West Siberian sedimentary basin]. Lithosphere, 2011, no. 6, pp. 38-54.

58. Kist A.A. Fenomenologiya biogeokhimii i bioneorganicheskoy khimii [Phenomenology of biogeochemistry and bio-nonorganic chemistry]. Tashkent, FAN7 Publ., 1987. 236 p.

59. Rikhvanov L.P. Obshchie i regionalnye problemy radioekologii [General and regional problems of radioecology]. Tomsk, TPI Publ., 1997. 384 p.

\section{Information about the authors}

Natalia V. Baranovskaya, Dr. Sc., professor, National Research Tomsk Polytechnic University.

Elena V. Ageeva, postgraduate student, National Research Tomsk Polytechnic University.

Bulat R. Soktoev, Cand. Sc., assistant professor, National Research Tomsk Polytechnic University.

Dina V. Narkovich, Cand. Sc., assistant professor, National Research Tomsk Polytechnic University.

Olga A. Denisova, Cand. Sc., assistant, Siberian State Medical University.

Tamara V. Matkovskaya, Dr. Sc., professor, Siberian State Medical University. 